\title{
TERAJU
}

Teraju: Jurnal Syariah dan Hukum

Volume 02 Nomor 02, September 2020

DOI: https://doi.org/10.35961/teraju.v2i02.95

\section{Wakaf: Perannya Dalam Peningkatan Ekonomi Umat}

\author{
Erizal \\ STAIN Sultan Abdurrahman Kepulauan Riau \\ erizal@stainkepri.ac.id
}

\begin{abstract}
Abstrak
Perwakafan atau wakaf merupakan pranata dalam keagamaan Islam yang sudah mapan. Dalam hukum Islam, wakaf tersebut termasuk ke dalam kategori ibadah kemasyarakatan (ibadah ljtimaiyah). Sepanjang sejarah Islam, wakaf merupakan sarana dan modal yang amat penting dalam memajukan perkembangan agama. Sebenarnya wakaf merupakan salah satu lembaga Islam yang sangat potensial untuk lebih dikembangkan guna membantu masyarakat yang kurang mampu. Sayangnya wakaf yang jumlahnya begitu banyak, pada umumnya pemanfaatannya masih bersifat konsumtif tradisional dan belum dikelola secara produktif professional.
\end{abstract}

Kata Kunci: Ekonomi, Umat, Wakaf

\begin{abstract}
Representation or endowment is an institution in an established Islamic religion. In Islamic law, this waqf is included in the category of community worship (Ijtimaiyah worship). Throughout Islamic history, waqf is a very important means and capital in advancing the development of religion. In fact waqf is one of the Islamic institutions which has the potential to be further developed to help disadvantaged people. Unfortunately there are so many endowments, in general their use is still traditional consumptive and not professionally managed professionally.
\end{abstract}

Keywords: Economy, Ummah, Waqf 


\section{Pendahuluan}

Kesejahteraan seluruh rakyat merupakan suatu yang di cita-citakan Negara Republik Indonesia. Dalam pembukaan UUD 1945 disebut bahwa salah satu tujuan nasional adalah memajukan kesejahteraan umum, dan di dalam batang Tubuh UUD 1945 Kesejahteraan sosial juga ditempatkan dalam bab tersendiri, yakni bab XIV.

Dilihat dari Pembukaan UUD 1945 dan Batang Tubuh UUD 1945 jelas bahwa pembangunan yang dilaksanakan di Indonesia ini tidak lain salah satu tujuannya adalah mewujudkan kesejahteraan sosial bagi seluruh rakyat Indonesia. Kemerdekaan yang diperjuangkan dengan berat diharapkan mampu meningkatkan kesejahteraan setiap warga negaranya dan mampu membebaskan mereka dari keterbelakangan, kemiskinan dan kebodohan.

Masyarakat Indonesia adalah masyarakat yang dikenal religius, dimana agama berpengaruh dalam pembentukan tata tingkah laku mereka. Oleh karena itu di Indonesia agama dijadikan salah satu acuan bagi program pembangunan nasional. Salah satu agama yang berkembang di Indonesia adalah Islam dan ia merupakan agama yang dianut oleh mayoritas penduduk Indonesia.

Sebagai satu sistem yang mengatur hubungan manusia, Islam tidak hanya mengatur hubungan manusia dengan Tuhan saja, tetapi juga mengatur hubungan manusia dengan dirinya sendiri, masyarakat, benda dan lingkungan hidupnya. Kedua hubungan itu harus berjalan serentak dan simultan. Dengan melaksanakan kedua hubungan itu, hidup manusia akan sejahtera baik dunia maupun akhirat. Jika dikaji secara cermat, ajaran Islam dengan tujuan pembangunan

1 .Harun Al-Rasid, Naskah UUD 1945 dan Batang Tubuh UUD 1945 sesudah empat kali diubah oleh MPR, UI Pres, 2004.
Nasional kita, akan di dapati titik temu diantara keduanya, yakni sama-sama untuk mencapai kesejahteraan hidup, baik lahir maupun batin, di dunia maupun di akhirat. $^{2}$

Secara harfiah yang dimaksud dengan kesejahteraan adalah keamanan dan keselamatan hidup. Dalam perkataan kesejahteran telah termasuk pengertian kemakmuran, yakni konsep yang menunjukkan keadaan, dimana setiap orang baik sebagai individu, maupun sebagai anggota masyarakat dapat memenuhi kebutuhannya dengan mudah. Untuk itu harus tersedia barang dan jasa yang dapat diperoleh dengan harga yang relatif murah. Dengan demikian yang dimaksud dengan kesejahteraan adalah keadaan orang hidup aman dan tentram serta dapat memenuhi kebutuhan hidupnya. ${ }^{3}$

Negara Indonesia masalah kesejahteraan sangat ditekankan. Islam sebagai salah satu Agama yang paling banyak penganutnya di Indonesia, memiliki beberapa lembaga yang diharapkan mampu membantu pemerintah memerangi kemiskinan penduduk, salah satu diantaranya adalah wakaf.

\section{Pembahasan}

\section{A. Pengertian Wakaf}

Secara bahasa, wakaf berasal dari kata "waqafa" sinonim kata "babasa" dengan makna aslinya berhenti, diam di tempat, atau menahan. Kata al-waqf adalah bentuk masdar (gerund) dari ungkapan waqfu al-syai, yang berarti menahan sesuatu. Sebagai kata benda, kata wakaf semakna dengan kata albabs. Kalimat : habitsu abbisu babsan dan

${ }^{2}$ Kumpulan Hasil Seminar wakaf, Depag RI, Dirjen Bimas Islam dan Penyelenggaraan Haji, 2004, hal. 118.

${ }^{3}$ Muhammad Daud Ali, 1995, 275 
kalimat abbastu ubbisu abbaasan maksudnya adalah waqaftu (menahan) ${ }^{4}$

Menurut Muhammad al-Khathib dalam kitab al-Iqna dan Dr.Wahbah Zuhaili dalam bukunya, Alfiqhu al-Islami wal Adillatubu kata 'Wakaf' atau "Waqf" berasal dari bahasa Arab "Waqafa" asal kata "Waqafa" berarti menahan atau "Berhenti" atau "Diam di tempat" atau "Tetap Berdiri". Kata "Waqafa-Yaqifu-Waqfan" sama artinya dengan "Habasa-Yahbisu-Tahbisan" (Fiqh wakaf hal 1 depag RI)

Menurut Istilah, pra ahl figh berbeda pendapat dalam mendefinisikan wakaf, sehingga mereka berbeda pula dalam memandang hakekat wakaf itu sendiri. Berbagai pandangan tentang wakaf menurut istilah sebagai berikut :

\section{Abu Hanifah}

Wakaf adalah menahan suatu benda yang menurut hukum tetap milik siwakif dalam rangka mempergunakan manfaatnya untuk kebajikan.

Berdasarkan defenisi ini maka pemilikan harta wakaf tidak lepas dari si wakif, bahkan ia dibenarkan menariknya kembali dan ia boleh menjualnya. Jika si wakif wafat, harta tersebut menjadi harta warisan buat ahli warisnya. Jadi yang timbul dari wakaf hanyalah "menyumbangkan manfaat" . Karena itu mazhab Hanafi mendefenisikan wakaf adalah : "Tidak melakukan suatu tindakan atas suatu benda yang berstatus tetap sebagai bak milik, dengan menyedekabkan manfaatnya kepada suatu pibak kebajikan (sosial) baik sekarang maupun akan datang".

\section{Mazhab Maliki}

Mazhab Maliki berpendapat bahwa wakaf itu tidak melepaskan barta yang diwakafkan dari kepemilikan wakif, namun wakaf tersebut mencegah wakif melakukan tindakan yang dapat melepaskan kepemilikannya atas harta tersebut kepada yang lain dan wakif berkewajiban menyedekahkan manfaatnya serta tidak boleh menarik kambali wakafnya. Perbuatan si wakif menjadikan manfaat hartanya untuk digunakan oleh mustabiq (penerima wakaf) walaupun yang dimilikinya itu berbentuk upah, atau menjadikan hasilnya untuk dapat digunakan seperti mewakafkan uang. Wakaf dilakukan dengan mengucapkan lafaz wakaf untuk masa tertentu sesuai dengan keinginan pemilik. Dengan kata lain, pemilik harta menahan benda itu dari kegunaan secara pemilikan, tetapi membolehkan pemanfaatan hasilnya untuk tujuan kebajikan, yaitu pemberian manfaat benda secara wajar sedang benda itu tetap menjadi milik si wakif. Perwakafan itu berlaku untuk suatu masa tertentu, dan karenanya tidak boleh di syaratkan sebagai wakaf kekal (selamanya).

3. Mazhab Syafi'i dan Ahmad bin Hambal

Syafi'i dan Ahmad berpendapat bahwa wakaf adalah melepaskan harta yang diwakafkan dari kepemilikan wakif, setelah sempurna prosedur perwakafan. Wakip tidak boleh melakukan apa saja terhadap harta yang diwakafkan, seperti : perlakukan pemilik dengan cara pemilikannya kepada yang lain, baik dengan tukaran atau tidak. Jika wakif wafat, harta yang diwakafkan tersebut tidak dapat diwarisi oleh ahli warisnya. Wakif menyalurkan manfaat harta yang diwakafkan kepada "Mauquf 'alaibi" (yang diberi wakaf) sebagai sedekah yang mengikat, dimana wakif tidak dapat 
melarang penyaluran sumbangannya tersebut. Apabila wakif melarangnya, maka qadli berhak untuk memaksakannya agar memberikan kepada mauquf 'alaibi, karena itu maszhab Syafi'i mendefenisikan wakaf: "Tidak melakukan suatu tindakan atas suatu benda, yang berstatus sebagai milike Allah SWT dengan menyedekabkan manfaanya kepada suatu kebajikan (sosial). ${ }^{5}$

4. Mazhab Malikiyah

Ibn Arafah mendefenisikan wakaf: "Memberikan manfaat sesuatu, pada batas waktu keberadaannya, bersamaan tetapnya wakaf dalam kepemilikan si pemiliknya meski hanya perkiraan (pengandaian)".

Memberikan manfaat sesuatu maksudnya adalah mengecualikan pemberian barang, seperti hibah, maka orang yang berhibah (memberi) berarti memberikan barang kepada orang yang dihibahkan. Sedangkan pada wakaf, yang diberikan adalah manfaatnya bukan barangnya.

Kalimat "Kepemilikannya tetap dipegang oleh pemberi wakaf " adalah kalimat memperjelas yang mengandung maksud bahwa orang yang berwakaf ibarat hamba yang melayani tuannya hingga meninggal. Kalimat "walaupun dengan perkiraan" menunjukkan bahw lafal itu menunjukkan maksud kepemilikan.

5. Menurut Ulama Zaidiyah

Pengarang Al-Syifa
memaknai Webagai
"Pemilikan Khusus, dan dengan niat
mendekatkan diri kepada Allah
SWT"

Kalimat "pemilikan khusus" artinya bukan penggadaian, penyewaan, di paksa atau terpaksa.
Sedangkan kalimat "dengan niat mendekatkan diri kepada Allah" hal itu tidak disyaratkan pada sesuatu, selain pada wakaf.

6. Menurut Hanabilah, Syi'ah dan Ja'fariyah

a. Menurut Ibnu Qudmah, wakaf adalah menahan yang asal dan memberikan hasilnya

b. Menurut Syamsudin Al-Maqdisy, wakaf adalah menahan yang asal dan memberikan hasilnya

c. Menurut Al-Muhaqiq Al-Huly dari kalangan Ja'fariyah wakaf adalah akad yang hasilnya adalah menahan yang asal dan memberikan manfaatnya

d. Muhammad Al-Husny mengartikan wakaf yaitu menahan barang dan memberikan hasilnya

Dari definisi-definisi diatas, defenisi yang terbaik menurut Muhammad Abid Abdullah AlKabisi adalah defenisi Ibn Qudamah (Muhammad Abid Abdullah AlKabisi, 2004 :61) hal ini karena defensi tersebut di kutif dari hadis nabi Muhammad SAW kepada Umar Bin Khattab R.A yang berbunyi :"menahan yang asli dan mengalirkan hasilnya" Selain itu, defenisi ini tidak di tantang sebagaimana defenisi lainnya Al- Bajuri mendefenisikan wakaf: "Menahan Harta tertentu untuk memindabkan manfaatnya kepada penerima dengan menetapkan asal benda tersebut dan jalur peredaran kepada kebaikan untuk mendekatkan diri kepada Allab SWT".

Benda tersebut dialihkan dengan maksud dialihkan penggunaannya untuk suatu tujuan yang tertentu yang berguna untuk kepentingan umum dan tidak bertentangan dengan ajaran agama 
Islam yag diridhoi Allah SWT. Maka dengan adanya perwakafan itu pemilik benda semula tidak memiliki lagi karena benda-benda tersebut lalu menjadi milik Allah SWT, dan digunakan untuk semua kepentingan yang diridhoi Allah SWT.

7. Mazhab Lain

Mazhab lain berpendapat sama dengan Mazhab diatas, namun berbeda dari segi kepemilikannya atas benda yang diwakafkan yaitu menjadi milik manquf 'alaibi (yang diberi wakaf), meskipun manquf 'alaibi tidak berhak melakukan suatu tindakan atas benda wakaf tersebut, baik menjual atau menghibahkannya.

Dari berbagai rumusan pengertian tentang wakaf diatas, dapat diartikan bahwa wakaf adalah memindahkan hak kepemilikan suatu benda abadi tertentu dari seseorang kepada orang lain (individu) atau organisasi Islam, untuk diambil manfaatnya dalam rangka ibadah mencari ridha Allah Swt.

\section{B. Dasar Hukum Wakaf}

Al quran dan Sunnah Nabi SAW sebagi sumber hukum Islam yang utama memberi petunjuk secara umum tentang amalan wakaf, sebab amalan wakaf termasuk salah satu yang digolongkan dalam perbuatan baik. Ayat-ayat Al-quran yang berkaitan dengan wakaf tersebut adalah :

1. Al-Quran surat Al-hajj ayat 77

Artinya: "wahai orang-orang yang beriman, rukuklab kamu, sujudlah kamu, sembahlah Tubanmu dan berbuatlah kebajikan, supaya kamu mendapat kemenangan".

Al Qurtubi mengartikan

"berbuat baiklab kamu" dengan pengertian perbuatan baik itu adalah perbuatan sunnah bukan perbuatan wajib, sebab perbuatan wajib adalah kewajiban yang sudah semestinya dilakukan hamba kepada Tuhannya (Al-Qurthubi, CD Program Holy Qur'an tafsir surat al-haij ayat 77), salah satu perbuatan sunnah adalah wakaf yang selalu menawarkan pahala disisi Allah SWT, bunyi akhir dari ayat di atas adalah "mudahmudahan kamu sekalian beruntung" adalah gambaran dampak positif dari perbuatan amal kebajikan termasuk wakaf.

2. Sunnah Rasulullah SAW.

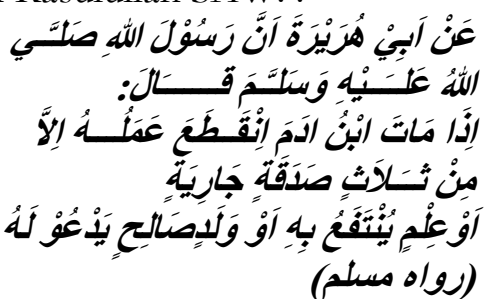

Artinya: "Dari Abu Hurairah $\mathrm{RA}$, sesunggubnya Rasululah $S A W$ bersabda "Apabila anak Adam (manusia) meninggal dunia maka putuslah amalnya kecuali tiga perkara : shadaqah jariyah, ilmu yang bermanfaat dan anak yang sholeh yang mendo'akan orang tuanya (HR. Muslim)

Dari hadis tersebut di atas dapat dipahami bahwa mewakafkan harta lebih utama ketimbang infak atau sedekah. Amalan wakaf lebih besar manfaatnya bagi kehidupan sosial ekonomi, keagamaan dan perkembangan kebudayaan. Sejarah telah mencatat bahwa dari hadishadis Nabi yang membicarakan tentang wakaf merupakan motivator kaum muslimin untuk berwakaf, giat mengadakan penelitian ilmiah, usaha-usaha pengembangan berbagai ilmu pengetahuan yang bermanfaat.

Contoh dalam bidang wakaf misalnya Universitas Al-Azhar di Mesir yang telah berumur 1.000 tahun lebih itu dibiayai dari harta 
wakaf, mahasiswa tugas belajar dari berbagai negara menerima bea siswa juga dari harta wakaf yang dikelolanya.

Di Jawa Timur, Pondok Modern Gontor di Ponorogo berkembang dengan baik dengan meyelenggarakan pendidikan mulai dari Taman Kanak-kanak hingga perguruan tinggi berkat kemampuan megelola tanah wakaf yang dimilikinya.

Sunah Rasulullah SAW :

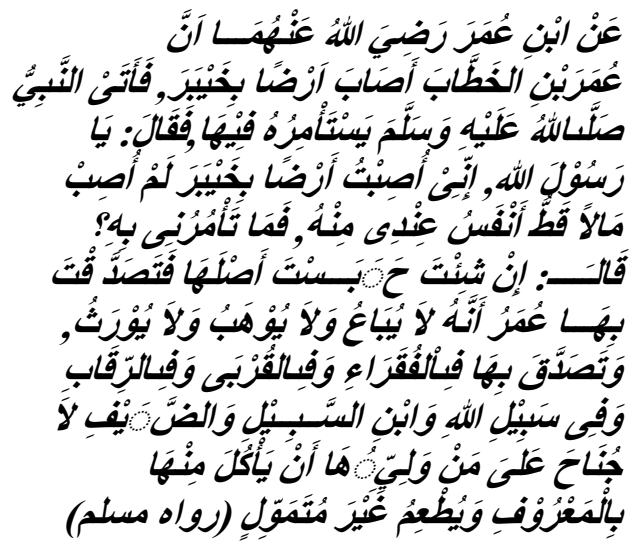

Artinya "Dari Ibnu Umar RA berkata , bahwa sahabat Umar $\mathrm{R} A$ memperoleh sebidang tanah di Khaibar, kemudian menghadap kepada Rasulullah untuk memohon petunjuk. Umar berkata : ya Rasulullah, saya mendapakan sebidang tanah di Khaibar, saya belum pernah mendapatkan harta sebaik itu, maka apakah yang engkau perintabkan kepadaku? Rasulullah menjawab : Bila kamu suka, kamu tahan (pokoknya) tanah itu, dan kamu sedekabkan (basilnya) Keudian Umar melakukan shadaqah, tidak dijual, tidak dibibabkan dan tidak pula diwariskan. Berkata Ibnu Umar : Umar menyedekabkannya kepada orang-orang fakir,kaum karabat, budak belian, sabilillah, ibnu sabil dan tamu. Dan tidak mengapa atau tidak dilarang bagi orang yangmenguasai tanah wakaf itu (pengurusnya) makan dar ihasilnya dengan cara baik (sepantasnya) atau makan dengan tidak bermaksud menumpuk harta" (HR. Muslim)

Dari hadis perihal wakaf Umar tersebut dapat diperoleh ketentuan-ketentuan sebagai berikut

a. Harta wakaf tidak dapat dipindahkan kepada orang lain ,baik dengan dijual belikan, diwariskan atau dihibahkan

b. Harta wakaf terlepas kepemilikannya dari Wakif (orang yang berwakaf)

c. Tujuan wakaf harus jelas dan termasuk amal kebajikan menurut pandangan Islam

d. Harta wakaf dapat dikuasakan kepada pengawas yang mempunyai hak untuk ikut menikmati harta wakaf sekedar perlunya dan tidak berlebihlebihan

e. Harta wakaf dapat berupa tanah dan lain sebagainya yang tahan lama, tidak musnah seketika setelah dimusnahkan.

Ayat alquran dan hadis nabi yeng menyinggung tantang wakaf sedikit sekali, karena itu sedikit sekali hukum-huum wakaf yang ditetapkan berdasarkan kedua sumber tersebut. Meskipun demikian, ayat alquran dan Sunnah yang sedikit itu mampu menjadi pedoman para ahli Figh Islam.

Sejak pada masa Khulafa'u Rasyidin sampai sekarang wakaf melalui ijtihad mereka. Sebab itu sebagian besar hukum-hukum wakaf dalam Islam ditetapkan sebagai hasil ijtihad, dengan menggunakan metode ijtihad yang bermacammacam, seperti qiyas dan lain-lain.

C. Wakaf dalam Sistem Peraturan Perundang-undangan di Indonesia

Keberadaan lembaga wakaf di Indonesia telah dikenal dan 
berlangsung seiring dengan usia agama Islam masuk ke Nusantara, yakni pada pertengahan abad ke $-13 \mathrm{M}$.

Lembaga wakaf di Indonesia pada kenyataannya telah menjadi penunjang utama perkembangan masyarakat Islam. Banyak rumah ibadah, perguruan pendidikan Islam dan lembaga keagamaan Islam lainnya bangunan fisiknya berada diatas tanah wakaf. Begitu juga aktifitas yang dijalankan diantaranya dari hasil wakaf umat Islam. Sebagai contoh di Jawa Timur antara tahun 1500-1600 telah berlangsung perwakafan. Berdasarkan data yang terdapat di Kantor Wilayah Departemen Agama Propinsi Jawa Timur dan Kantor Urusan Agama, selama abad XVI terdapat enam buah wakaf dengan luas 20.615 M2. Pada pertengahan abad XVIII terdapat 61 wakaf dengan luas 94.071 M2 (rata-rata 1.542 perwakaf),yang terdiri dari 57 wakaf tanah kering dan 4 buah wakaf sawah. Pada waktu ini baru pertama kali terdapat wakaf sawah yang luasnya $9.850 \mathrm{~m} 2$ untuk memelihara kuburan di Kabupaten Probolinggo. Kemudian wakaf tanah meluas kedaerah-daerah pasuruan, Kediri dan Madium. Pada abad XIX tercatat pada Kantor Wilayah Departemen Agama Propinsi Jawa Timur 303 lokasi tanah wakaf milik. Jumlah tersebut pada pertengahan pertama abad XIX tercatat 79 buah wakaf yang terdiri dari 78 wakaf tanah kering dan sebuah wakaf sawah. Pada pertengahan kedua abad tersebut,tercatat 224 buah wakaf terdiri dari219 buah wakaf tanah kering dan 5 buah wakaf sawah.

Dikalangan kaum muslimin, perwakafan khususnya menyangkut tanah terus berlangsung, walaupun pada kenyataannya wilayah Indonesia dijajah oleh Pemerintah Kolonial Belanda. Pada masa pemerintah Kolonial Belanda telah dikeluarkan beberapa peraturan di bidang perwakafan tanah,termasuk didalamnya masjid dan rumah suci, yaitu sebagai berikut :

a. Bijblad op het Staatsblad Nomor : 6196 tanggal 31 Januari 1905 tentang Bedebuizen Moskieen (Rumah-rumah suci dan Masjid). Dalam Bijblad ini dinyatakan bahwa bagi mereka yang ingin melaksanakan wakaf diharuskan terlebih dahulu meminta izin kepada Bupati, akan tetapi peraturan ini dianggap oleh umat islam sebagai alat untuk membatasi ibadah mereka Bijblad itupun memerintahkan Bupati supaya mendaftarkan tanah wakaf dan masjid.

b. Bijblad op het Staatsblad nomor 12573, tanggal 4 Juni 1931 tentang Bedehuizen en Wakaps. Peraturan ini dengan tegas menyatakan bahwa tanah yang akan di bangun masjid harus terlebih dahulu diminta izin oleh si wakif dari penguasa, dalah hal ini pemerintah Hindia Belanda. Permintaan izin tersebut dimaksudkan agar tanah yang dibangun Masjid diatasnya dikemudian hari tidak terganggu atau tergusur oleh pembangunan Kota.

c. Bijblad op het staat sblad Nomor : 13390 tanggal 24 Desember 1934 tentang Bedehuizen Vrijdageisten Moskieen ,en Wakaf. Peraturan ini bukan saja mengatur wakaf tanah dan pembangunan masjid, melainkan juga mengatur perizinan Sholat Jum'at (Vridagdiest en Wakaps). Peraturan ini tetap tidak mendapat sambutan masyarakat Islam. Tanah wakaf tetap tidak terdaftar, kecuali sebagian kecil saja.

d. Bijbladop het Staatsbalad Nomor :13480 tanggal 27 Mei 1935 tentang BedehuizenV rijd V rijdagdiesten Moskien en Wakaf, yang memerintahkan 
Bupati untuk mendaftarkan tanah wakaf, orang yang mewakafkan tanahnya harus terlebih dahulu melaporkannya kepada bupati, Bupati kemudian melaporkannya kepada Kadaster. Kadaster melaporkannya kepada bagian pajak agar membebaskan beban pajak atas tanah yang diwakafkan.

Dalam prakteknya beberapa peraturan yang dikeluarkan oleh pemerintah Kolonial Belanda tersebut tidak berjalan sebagaimana mestinya. Hal tersebut berlanjut hingga pada masa pendudukan Jepang, setelah kemerdekaan Indonesia pada tanggal 17 Agustus 1945, peraturan tentang perwakafan yang dikeluarkan oleh pemerintah Kolonial Belanda masih berlaku. Berdasarkan ketentuan pasal II aturan peralihan Undang-Undang Dasar 1945. yang berbunyi "Segala badan Negara dan peraturan yang masib ada masib langsung berlaku selama belum diadakan yang baru menurut UndangUndang Dasar ini." 7

Disamping itu Pemerintah Republik Indonesia mengeluarkan beberapa peraturan tentang perwakafan, antara lain:

a. Petunjuk Tentang Wakaf dari Departemen Agama tanggal 22 Desember 1953.

b. Petunjuk Tentang Wakaf yang bukan milik Kemasjidan merupakan tugas bagian D (ibadah sosial) Jawatan Urusan Agama berdasarkan surat edaran Jawatan urusan Agama tanggal 8 Oktober 1956 nomor : 3/D/1956.

c. Petunjuk Tentang Prosedur Perwakafan Tanah Berdasarkan Surat Edaran Jawatan Urusan Agama Nomor : 5/1956.

7 Perkembangan Pengelolaan Wakaf di Indonesia, Proyek Peningkatan zakat dan wakaf Dirjen BIPH Depag RI, 2003, 14.
Peraturan tentang wakaf, baik produk pemerintah Kolonial Belanda maupun yang buat oleh pemerintah Republik Indonesia ,ternyata dirasakan masih banyak kelemahan, terutama dalam memberikan kapastian hukum bagi tanah-tanah wakaf. Dalam rangka penertiban tanah wakaf dan dan pembaruan hukum agraria di Indonesia, masalah perwakafan tanah mendapat perhatian dari pemerintah.Hal ini dapat dilihat dalam pasal 49 Undang-Undang Nomor 5 tahun 1960 tentang Peraturan Dasar Pokok-Pokok Agraria yang berbunyi :

a. Hak milik tanah badan-badan keagamaan dan social sepanjang digunakan untuk usaha dalam bidang keagamaan dan sosial, diakui dan dilindungi .Badan-badan tersebut dijamin pula akan memperoleh tanah yang cukup untuk bangunan dan usahanya dalam bidang keagamaan dan sosial.

b. Untuk keperluan peribadatan dan keperluan suci lainnya sebagai dimaksud pasal 14 dapat diberikan tanah yang dikuasai langsung oleh Negara dengan hak pakai.

c. Perwakafan tanah milik dilindungi dan diatur oleh Peraturan Pemerintah.

Realisasi ketentuan pasal 49 ayat (3) di atas, kemudian dikeluarkan Peraturan Pemerintah nomor 28 tahun 1977. Sebagai tindak lanjut telah dikeluarkan beberapa peraturan pelaksanaannya yaitu ;

a. Peraturan Menteri Dalam Negeri No.6 tahun 1977 tentang Tata Pendaftaran Tanah mengenai perwakafan tanah milik.

b. Peraturan Menteri Agama Nomor:1 Tahun 1978 tentang Peraturan Pelaksanaan Peraturan Pemerintah Nomor 28 Tahun 1977 tentang Perwakafan Tanah Milik. 
c. Keputusan Menteri Agama nomor 73 tahun 1978 tentang Pendelegasian Wewenang pada Kepala Kanwil /setingkat di seluruh Indonesia untuk mengangkat /memberhentikan setiap Kepala Kantor Urusan Agama Kecamatan sebagai Pejabat Pembantu Pembuat Akta Ikrar Wakaf.

d. Instruksi Menteri Agama Nomor : 3 Tahun 1978 tentang petunjuk pelaksanaan Keputusan Menteri Agama Nomor :73 tahun 1978 tentang pendelegasian wewenang Kepada Kepala Kanwil Departemen Agama Propinsi/setingkat untuk mengangkat/memberhentikan setiap Kepala Kantor Urusan Agama Kecamatan sebagai Pejabat Pembuat Akta Ikrar Wakaf.

e. Intruksi Menteri Agama nomor :3 tahun 1978 Tentang Bimbingan dan Pembinaan kepada badan hukum Keagamaan sebagai nadzir dan badan hukum keagamaan yang memiliki tanah.

f. Keputusan Menteri Agama nomor :326 tahun 1989 tentang Pembentukan Tim Koordinasi Penertiban Tanah Wakaf Seluruh Indonesia Tingkat Pusat.

g. Intruksi Menteri Agama Nomor :15 tahun 1989 tentang pembuatan Akta Ikrar Wakaf dan Pensertifikatan Tanah Milik.

h. Instruksi Menteri Agama dan Kepala Badan Pertanahan Nasional Nomor : 4 tahun 1990 tentang Sertifikat Tanah Wakaf.

i. Beberapa Surat Keputusan dan Surat Edaran Dirjen Bimas Islam dan Urusan Haji yang berkenaan dengan perwakafan.

j. Undang-Undang Republik Indonesia Nomor: 41 tahun 2004 Tentang Wakaf. ${ }^{8}$

\section{${ }^{8}$ ibid}

Dilihat dari sejarah singkat peraturan perwakafan sebagaimana telah diatur dalam perundangundangan di Indonesia relatif memakan waktu panjang, dan dapat dipahami bahwa pelaksanaannya hingga saat ini belum sempurna sesuai dengan yang diharapkan, namun upaya-upaya terus dilakukan yaitu dengan pembaruan Hukum Nasional di Bidang Perwakafan.

Salah satu usaha reformasi Hukum yang perlu dilaksanakan adalah memberikan akses dan kemudahan bagi umat Islam untuk menempatkan lembaga sosial Ekonomi Islam dalam tatanan aturan hukum positif dalam bentuk Undang-undang. hal itu diperlukan untuk memberikan kebebasan dan tempat bagi umat Islam dengan semenimal mungkin terhindar dari perlakuan yang diskriminatif.

Guna memujudkan sistem hukum nasional yang berpijak pada hukum yang hidup di dalam masyarakat, maka hukum Islam sebagai bagian sistem nasional harus dijadikan sumber hukum dalam pembentukan hukum nasional.

Problem yang terbesar di bidang hukum di Indonesia pada saat sekarang adalah supremasi hukum dan hak asasi manusia berdasarkan keadilan dan kebenaran secara obyektif masih jauh dari harapan masyarakat. Salah satu yang mempengaruhi adalah belum terciptanya materi hukum yang berpijak pada keyakinan yang tumbuh dan dipelihara oleh masyarakat baik berdasarkan kebiasaan maupun berdasarkan agama.

Lembaga wakaf walaupun secara qat'i tidak disebut didalam alqur'an tetapi setidaknya telah menjadi bagian dan diakui eksistensinya didalam pergaulan hidup umat Islam.

Secara umum kebijaksanaan pembaruan hukum selama ini telah 
dilakukan pemerintah diarahkan kepada

1) Pembangunan materi hukum aparatur hukum serta sarana dan prasarana hukum dalam rangka pembangunan negara hukum untuk menciptakan kehidupan masyarakat yang aman dan tenteram.

2) Pembangunan hukum dilaksanakan melalui pembaruan hukum dengan tetap memperhatikan kemajemukan tatanan hukum yang berlaku, yang mencakup upaya untuk meningkatkan kesadaran hukum, penegakan hukum dan pelayanan hukum yang berintikan keadilan dan kebenaran dalam rangka penyelenggaraan Negara yang makin tertib dan teratur serta penyelenggaraan pembangunan Nasional yang lancar.

3) Lahirnya Undang-undang nomor : 41 Tahun 2004 tentang wakaf

D. Menggerakkan Ekonomi Umat Dengan Mengefektifkan Wakaf

Wakaf adalah suatu lembaga sosial Islam yang lazim dipahami "menaban sesuatu benda untuk diambil manfaatnya dan kelembagaan guna kepentingan umum, "artinya benda itu tidak dialihkan kepada siapapun dan dijadikan sebagai suatu lembaga sosial yang dapat dimanfaatkan untuk umum (for the public utility).Dilihat dari sudut Al-Qur'an, doktrin ini dapat disandarkan pada konsep dasar ajaran Islam tentang "amal Shaleh" sebagai pengejawantahan dari Iman, salah satu bentuk amal shaleh itu adalah wakaf.

Pemahaman konteks atas ajaran wakaf juga diambilkan dari beberapa Hadits Nabi yang menyinggung masalah shadaqah jariyah, yaitu :Sunnah Rasulullah SAW.

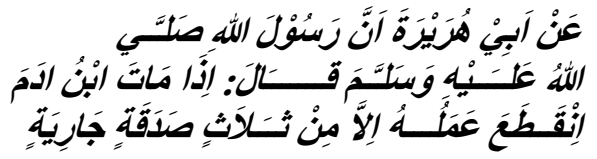

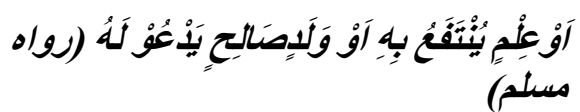

Artinya: Dari Abu Hurairah RA., sesunggubnya Rasulullab $S A W$ bersabda: "Apabila anak Adam (manusia) meninggal dunia, maka putuslah amalnya, kecuali tiga perkara : shadaqah jariyah, ilmu yang bermanfaat dan anak shaleh yang mendoakan orang tuanya (HR. Muslim).

Hadis ini dapat dipahami secara alternatif artinya apabila ada salah satu di antara tiga hal yang disebutkan oleh nabi Muhammad SAW tersebut, itu sudah cukup bagi seorang muslim untuk dipandang amalnya masih berlanjut sekalipun ia sudah meninggal. Apabila shadaqab jariab itu diwujudkan dalam bentuk suatu benda, terutama benda yang tidak bergerak, seperti tanah yang digambarkan dalam dialog antara Rasulullah SAW dengan Umar bin Khattab RA yang memiliki sebidang tanah di Khaibar (Madinah) dan tanah itu sangat ia sukai, Umar bertanya kepada Rasulullah SAW, apakah saya lepaskan tanah itu sebagai shadaqah untuk mendekatkan diri kepada Allah? Nabi menjawab, "Tahanlab pokoknya dan sedekabkan basilnya".

Dilihat dari sudut hukum, Nabi mengajarkan, supaya eksistensi tanah itu berlangsung terus, maka yang disedekahkan atau dibagikan kepada umum, manfaat (hasil) dari tanah itu. Hasil atau produk dari tanah itu mengandung banyak kemungkinan, misalnya hasil pertanian, kalau tanah itu digunakan untuk pertanian, hasil tambang, kalau tanah itu mengandung emas atau bahan logam lainnya, minyak atau gas bumi, hasil produk suatu pabrik, kalau tanah itu digunakan untuk pabrik dan lain-lain. Dengan kata lain, jawaban Rasulullah SAW yang singkat itu, dapat memberikan berbagai interprestasi sesuai dengan 
perkembangan sosial , ekonomi manusia, di suatu tempat dan masa.

$$
\text { Dalam pengertian "Habas" }
$$

(menahan) yang dimaksud Rasulullah tidak mengalihkan kepemilikan tanah itu kepada siapapun, kecuali menjadikannya sebagai suatu lembaga sosial kepunyaan umum dalam makna untuk kepentingan amal ibadah dan amal sosial. Dengan demikian, melalui wakaf sebagai salah satu Lembaga Sosial Islam (LSI) seseorang Muslim dapat mewujudkan secara konkret doktrin Islam yang sangat esensial "Hublum min Allab wa bablum min alnas", artinya : "Hubungan dengan Allah dan hubungan antara manusia serta lingkungan hidupnya”. Kedua macam hubungan ini sering dinamakan hubungan vertikal (ibadah) dan hubungan horizontal (mu'amalah, kemasyarakatan).

Di dalam Undang-undang Nomor : 41 tahun 2004 tentang wakaf disebutkan ada dua benda yang bisa diwakafkan :

1. Benda tidak bergerak meliputi :

a. hak atas tanah sesuai dengan ketentuan peraturan perundangundngan yang berlaku baik yang sudah maupan yang belum terdaftar

b. bangunan atau bagian bangunan yang berdiri diatas tanah sebagaimana dimaksud pada huruf a

c. tanaman dan benda lain yang berkaitan dengan tanah

d. hak milik atas satuan rumah susun sesuai dengan ketentuan peraturan perundang-undangan yang berlaku

e. benda tidak bergerak lain sesuai dengan ketentuan syari'ah dan peraturan perundang-undangan yang berlaku.
2. Benda bergerak adalah benda yang tidak bisa habis karena di konsumsi, meliputi :

a. uang logam

b. logam mulia

c. surat berharga

d. kendaraan

e. hak atas kekayaan intelektual

f. hak sewa; dan

g. benda bergerak lain sesuai dengan ketentuan syari'ah dan peraturan perundang-undangan yang berlaku'

Bila benda wakaf diatas dikelola secara baik maka pungsi wakaf yaitu "mewujudkan potensi dan manfaat ekonomis harta benda wakaf untuk kepentingan ibadab dan untuk memajukan kesejabteraan umum $^{\text {,10 }}$ akan cepat terujud, ungkapan ini bisa diyakini karena wakaf memponyai potensi yang sangat besar.

Dari tinjauan hukum Islam, wakaf mirip dengan economic corporation dimana terdapat modal untuk dikembangkan yang keuntungannya digunakan bagi kepentingan umat. Yang lebih menjamin keabadian wakaf tersebut adalah adanya ketentuan tidak boleh menjual atau mengubah asset itu menjadi barang konsumtif, tetapi tetap terus menjadikannya sebagai asset produktif.

Investasi harta melalui wakaf sebenarnya juga merupakan sesuatu yang amat unik yang berbeda dengan investasi disektor pemerintah (public sector) maupun sektor swasta (private sector) begitu uniknya sektor wakaf ini bahkan kadang-kadang disebut sebagai sektor ketiga (third sector) yang berbeda dengan sektor pemerintah dan swasta.

Keunikan itu tampak bahwa pengembangan harta melalui wakaf tidak didasarkan pada target pencapain keuntungan bagi pemodal baik pemerintah maupun swasta tetapi lebih

$$
\begin{aligned}
& { }_{9}^{9} \text { Loc Cit } \\
& { }^{10} \text { Ibid }
\end{aligned}
$$


didasarkan pada unsur kebajikan (birr), kebaikan (ibsan) dan kerja sama. Selain itu secara teoritis, asset yang diwakafkan semestinya harus terus terpelibara dan berkembang. $\mathrm{Hal}$ ini terlihat dari adanya larangan untuk mengurangi asset yang telah diwakafkan (al-amal al-mawqif) atau membiarkannya tampa diolah atau dimanfaatkan apalagi untuk menjualnya.

Dibeberapa kota di Timur Tengah seperti Mekkah, Kairo dan Damaskus. Masjid-masjid yang ada banyak di bongkar dan dibangun kembali menjadi beberapa lantai di atas tanah yang sama. Lantai satu digunakan untuk masjid, lantai dua digunakan untuk ruang bimbingan belajar bagi anak-anak sekolah, lantai tiga untuk balai pengobatan, lantai empat untuk ruang pertemuan serbaguna dan begitu seterusnya. Semua itu diolah dengan sistem profit yang menjamin pengembangan investasi wakaf. Pendapatan yang di dapatnya cukup besar. $^{11}$

Wakaf dalam doktrin Islam merupakan salah satu bentuk "amal jariab". Di dalam sejarah Islam dikenal ada cash waqf yang sudah dipraktekkan sejak awal abad kedua hijriyah. Diriwayatkan oleh Imam Bukhori, bahwa Imam Az-zuhri (wafat $124 \mathrm{H}$ ) salah seorang ulama terkemuka dan peletak dasar tadwin al-hadits menfatwakan "dianjurkan wakaf dinar dan dirham untuk pembangunan sarana dakwah, sosial, pendidikan Umat Islam. Adapun caranya adalah dengan menjadikan uang tersebut sebagai modal usaba kemudian menyalurkan keuntungannya sebagai wakaf.

$$
\text { Menurut Mazhab Hanafi }
$$

(Wahbab Al-Zuhaily, 1997) bahwa uang yang diwakafkan dijadikan modal usaha dengan sistem Mudlarabah atau

11 Heri Sucipto, Mengembangkan Wakaf Belajar Dari Timur Tengah, Makalah, 2004 sistem bagi hasil. Keuntungan dari bagi hasil diberikan untuk kepentingan umum. ${ }^{12}$

Ada empat manfaat utama dari wakaf uang yang mulai digalakkan dewasa ini.:

Pertama, wakaf uang jumlahnya bisa bervariasi sehingga seseorang yang memiliki dana terbatas sudah bisa mulai memberikan dana wakafnya tampa harus menunggu menjadi tuan tanah terlebih dahulu.

Kedua, melalui wakaf uang asetaset wakaf yang berupa tanah-tanah kosong bisa mulai dimanfaatkan dengan pembangunan gedung atau diolah untuk menjadi lahan pertanian.

Ketiga, dana wakaf tunai juga bisa membantu sebagian lembagalembaga pendidikan Islam yang cash flownya terkadang kembang kempis dan mengaji civitas akademika alakadarnya .

Keempat, pada gilirannya, Insya Allah umat Islam dapat lebih mandiri dalam mengembangkan dunia pendidika tampa harus terlalu tergantung pada anggaran pendidikan negara yang memang semakin lama semakin terbatas. ${ }^{13}$

Melihat sangat strategisnya wakaf tunai ini, Komisi fatwa Majelis Ulama Indonesia pada tanggal 11 Mei 2002 bertepatan dengan tanggal 28 Shafar $1423 \mathrm{H}$, pernah menfatwakan tentang wakaf uang, dan menetapkan :

a. Wakaf uang (cash waqf) adalah wakaf yang dilakukan seseorang, kelompok orang, lembaga atau badan hukum dalam bentuk uang tunai.

b. Termasuk dalam pengertian uang adalah surat-surat berharga.

c. Wakaf uang hukumnya jawaz. (boleh) 
d. Wakaf uang hanya boleh disalurkan dan digunakan untuk hal-hal yang dibolehkan secara syar'i

e. Nilai pokok wakaf uang harus dijamin kelestariannya, tidak boleh dijual, dihibahkan, dan atau diwariskan.

Secara material, nilai wakaf bila dikelola secara baik dan benar, profesional dan transparan, nilainya amat fantastis Dan bisa menjadi alternatif penanganan penangulangan kemiskinan.

Sebagai contoh penduduk muslim Batam 530.000,- orang mempunyai penghasilan rata-rata Rp. 750.000,- perbulan, apabila masingmasing menyisihkan untuk wakaf $\mathrm{Rp}$. 5000,- perbulan maka akan terkumpul dana sebesar Rp.2.650.000,000,- (Dua Milyar Enam Ratus Lima Puluh Juta Rupiah) apabila dikalikan setahun maka akan terhimpun dana sebesar Rp. 31.800.000.000,- (Tiga Puluh Satu Milyar Delapan Ratus Juta Rupiah)

Kalau 10 juta orang saja dari umat Islam di Indonesia ini menyerahkan Rp. 100.000,- untuk wakaf. Maka dalam kalkulasi sederhana akan diperoleh Rp. 1 Trilyun dana wakaf tunai. Dana Ini diserahkan ke pengelola profesional yang memberi jaminan esensi. Jumlahnya tak akan berkurang dan malah bertambah karena digulirkan sebagai investasi. Apa yang segera di dapat ? Umpama dana tersebut di dititipkan di bank syari'ah dan setelah setahun diberikan bagi hasil, sembilan persen, maka pada akhir tahun sudah ada dana sebesar Rp. 90 miliar.

Banyak yang bisa ditolong dengan dana itu, sekian ribu anak yatim akan bisa disantuni, sekian puluh Sekolah Dasar dapat dibangun, sekian Balai Kesehatan bisa didirikan, sekian petani maupun pedang kecil bisa di modali,sekian banyak nelayan bisa di bantu. Ini baru kalau 10 juta penduduk, seandainya nominal perwakaf tunai Rp. 1000.000,- (satu juta) maka dananya sepuluh kali lipat mencapai Rp. 10 Trilyun, sangat fantastis.

Namun ada tiga filosofi dasar yang harus ditekankan ketika kita hendak menerapkan prinsip cash waqf terutama dalam dunia pendidikan.

Pertama alokasi Cash Waqf harus dilihat dalam bingkai "Proyek terintegrasi" bukan dana wakaf akan habis, bila dipakai untuk membayar gaji guru atau upah bangunan. Sementara wakaf harus "abadi" dengan bingkai proyek. Sesungguhnya dana wakaf akan dilokasikan untuk program-program pendidikan dengan segala macam biaya yang terangkum di dalamnya.

Kedua, asas kesejabteraan Nazhir. Sudab terlalu lama nazhir sering kali diposisikan kerja asal-asalan alias lillabita'ala (dalam pngertian mengisi sisa-sisa waktu bukan perhatian utama) dan wajib "berpuasa" sebagai akibatnya sering kali kinerja nazhir asal-asalan juga. Sudah saatnya kita menjadikan nazhir sebagai profesi yang memberikan kesejahteraan, bukan saja di akhirat, tetapi juga di dunia. Di Turki misalnya Badan Pengelola wakaf mendapatkan alokasi 5 persen dari net income wakaf. Angka yang sama juga diterima Kantor Administrasi wakaf Bangladesh. Sementara itu The Central Waqf council India mendapatkan sekitar 6 persen dari net income pengelolaan dana wakaf.

Ketiga, azas transparansi dan accountability dimana Badan Wakaf dan Lembaga yang dibantunya harus melaporkan setiap tahun akan proses pengelolaan dana kepada umat dalam bentuk andited financial report termasuk kewajaran dari masing-masing pos biayanya.

Dr. Muhammad Abid Abdullah Al-Kabisi seorang pakar Syari'ah dari 
Universitas Al-Azhar Mesir menyebutkan bahwa sasaran wakaf bisa dilihat secara umum dan khusus;

Secara umum wakaf memiliki fungsi sosial, Allah memberi manusia kemampuan dan karakter yang beraneka ragam. Dari sinilah kemudian timbul kondisi dan lingkungan yang berbeda di antara masing-masing individu. Ada yang miskin, kaya cerdas, bodoh, kuat dan lemah. Di balik semua itu tersimpan hikmah. Dimana Allah memberi kesempatan kepada yang kaya menyantuni yang miskin, yang cerdas membimbing yang bodoh dan yang kuat menolong yang lemah. Yang demikian merupakan wahana bagi manusia untuk melakukan kebaiikan sebagai upaya mendekatkan diri kepada Allah sehingga interaksi antar manusia terjalin.

Imam Dahlawi (nama lengkapnya adalah Ahmad bin Abdurrahim Al-Faruqi Al-Dahlawi yang dijuluki dengan Syah Waliyullah (1110-1176) ia seorang ahli figh dari mazhab Hanafi. Ia mempunyai beberapa karangan, diantaranya $\mathrm{Al}-$ Faruq al-Kabir fi Ushul Al-Tafsir) berkata : wakaf memiliki keistimewaan yang tidak dimiliki oleh jenis shadaqah lain. Manusia bisa jadi menginfaqkan hartanya dalam jumlah yang sangat besar. Akan tetapi infaq tersebut tidak bertahan lama, atau bahkan habis secara langsung. Padahal masih ada orang-orang miskin yang membutuhkan santunan. Karena itu alangkah lebih baik harta yang diinfakkan tadi berbentuk infak paten (wakaf) yang dapat bertahan lama. Sehingga bila ada orang-orang miskin yang memerlukan santunan. Infak yang paten tersebut dapat terus dimanfaatkan.

Sasaran wakaf bukan sekedar untuk orang fakir dan miskin. Namun juga untuk kepentingan publik dan masyarakat luas. Misalnya saja Untuk kepentingan bidang pendidikan, yaitu dengan mewakafkan tanah atau bangunan untuk belajar. Dari wakaf tersebut akan lahir kegiatan keilmuan yang pesat dalam masyarakat. Pada akhirnya lembaga pendidikan tersebut dapat melahirkan ulama dan cendikiawan yang handal.

Undang-undang Nomor 41 Tahun 2004 tentang Wakaf Pasal 22 dan 23 menyebutkan peruntukan harta benda wakaf adalah sebagai berikut: Pasal 22:

"Dalam rangka mencapai tujuan dan fungsi wakaf harta benda wakaf hanya dapat diperuntukan bagi:

a. Sarana dan kegiatan ibadah;

b. Sarana dan kegiatan pendidikan serta kesehatan;

c. Bantuan kepada fakir miskin, anak terlantar, yatim piatu, bea siswa;

d. Kemajuan dan peningkatan ekonomi umat; dan/atau

e. Kemajuan kesejahteraan umum lainnya yang tidak bertentangan dengan syariah dan peraturan perundang-undangan;

Peruntukan harta benda wakaf lainnya, sebagaimana yang disebutkan di dalam Pasal 23 Undang-undang Nomor 41 Tahun 2004 adalah:

(1) Penetapan peruntukan harta benda wakaf sebagaimana dimaksud dalam Pasal 22 dilakukan oleh Wakif pada pelaksanaan ikrar wakaf;

(2) Dalam hal Wakif tidak menetapkan peruntukan harta benda wakaf, Nazhir dapat menetapkan peruntukan harta benda wakaf yang dilakukan sesuai dengan tujuan dan fungsi wakaf;

Sedangkan sasaran khusus dilihat dari niat orang yang berwakaf,

a. Ada kalanya orang yang mewakafkan harta kekayaannya berniat untuk mendapatkan pahala 
atau untuk menebus dosa. Dengan mengeluarkan wakaf tersebut, dia akan merasakan ketenangan atau kepuasaan hidup. Dari sisi ini wakaf telah berperan sebagai sarana untuk mewujudkan sesuatu yang diniatkan oleh seorang wakif (pewakaf). Allah berfirman : dan Carilah wasilah (sarana) untuk menuju kepada-Nya (Qs Al-Maidah (5) 35) Motivasi seperti ini merupakan motivasi yang dilahirkan dari semangat keagamaan.

b. Semangat sosial. Ini didasarkan pada kesadaran manusia untuk berpartisipasi dalam kegiatan bermasyarakat. Sehingga wakaf yang dikeluarkan merupakan bukti partisipasi dalam pembangunan masyarakat.

c. Motivasi keluarga. Orang yang berwakaf kepada keluarga, ingin menjadikan hal itu sebagai sarana mewujudkan rasa tanggung jawab kepada keluarga. Terutama sebagai jaminan hidup masa depan, hal ini senada dengan sabda Nabi kepada Sa'ad bin Abi Waqqash 'Jika kamu meninggalkan keluargamu dalam keadaan kaya, itu lebih baik dari pada kamu meninggalkan mereka dalam keadaan miskin, Sebingga mereka meminta-minta kepada orang lain.

d. Dorongan kondisional. Ini terjadi jika seseorang yang ditinggalkan keluarganya, sehinga tidak ada yang akan menanggungnya. Atau seorang perantau yang jauh meningalkan keluarga. Dengan sarana wakaf, sipewakaf bisa menyalurkan hartanya untuk menyantuni orangorang tersebut.

e. Dorongan naluri. Naluri manusia memang tidak ingin lepas dari kepemilikannya. Setiap orang cendrung ingin menjaga peninggalan harta orang tua atau kakeknya dari kehancuran atau kemusnahan. Setiap orang juga tidak berharap harta peninggalan leluhurnya cepat habis, karena ulah anak-anak mereka atau karena ingin selalu membelanjakannya. Dengan mewakafkan harta tersebut, maka akan terdorong untuk membatasi pembelanjaan. Dengan niat wakaf kepada seseorang atau lembaga tertentu, dia bisa menyalurkan hartanya dengan baik, sehingga tidak kuatir terjadi pemborosan atau kepunahan kekayaaan. ${ }^{14}$

Bangsa Indonesia sudah memiliki Undang-Undang Nomor 41 Tahun 2004 tentang Wakaf yang merupakan landasan bagi pengembangan wakaf di Indonesia, dengan penduduk yang mayoritas Muslim dan dipimpin oleh Kepala Negara yang muslim maka para pakar, Departemen Agama, Ulama dan tokoh masyarakat tinggal menggerakkan potensi tersebut karena sesungguhnya motivasi umat Islam untuk menunaikan wakaf tersebut sudah ada.

Begitu besarnya potensi wakaf ini maka sudah selayaknya lembagalembaga wakaf dikembangkan dan didukung agar kesejahteraan dan citacita bersama mewujudkan bangsa Indonesia yang "Baldatun Thayyibatun Warabbun Ghafur" bisa segera kita wujudkan, wallahu'alam.

\section{Kesimpulan}

Berdasarkan uraian serta penjelasan di atas, dapat diambil kesimpulan sebagai berikut :

1. Keberadaan Wakaf di Indonesia telah di kenal dan berlangsung seiring dengan usia Agama Islam masuk ke Nusantara pada pertengahan abad ke$13 \mathrm{M}$ dan telah mengeluarkan beberapa aturan terkait dengan wakaf tersebut, yang puncaknya adalah UndangUndang Nomor : 41 Tahun 2004

${ }^{14}$ Hukum wakaf, OfCit, 85 
Tentang Wakaf namun belum bisa berjalan secara efektif disebabkan karena belum adanya peraturan pelaksanaan yang mengatur hal tersebut, juga disebabkan kurangnya sosialisasi dan Sumber Daya Manusia.

2. Harta benda wakaf tidak boleh habis sebagaimana ungkapan Nabi SAW "Tahanlah pokoknya dan sedekabkan hasilnya". Dilihat dari sudut hukum, Nabi mengajarkan, supaya eksistensi tanah itu berlangsung terus, maka yang disedekahkan atau dibagikan kepada umum, manfaat (hasil) dari tanah itu. Hasil atau produk dari tanah itu mengandung banyak kemungkinan, misalnya hasil pertanian, kalau tanah itu digunakan untuk pertanian, hasil tambang, kalau tanah itu mengandung emas atau bahan logam lainnya, minyak atau gas bumi, hasil produk suatu pabrik, kalau tanah itu digunakan untuk pabrik dan lain-lain. Dengan kata lain, jawaban Rasulullah SAW yang singkat itu, dapat memberikan berbagai interprestasi sesuai dengan perkembangan sosial, ekonomi manusia, di suatu tempat dan masa.

\section{Daftar Pustaka}

Abd. Al-Wahab Ibrahim Abu Sulaiman, alFiker al-Usyulyy, Dirasah Tahliyah Naqdiyah, Jeddah Dar al-Syryq, 1983.

Abdillah, Kudrat, Maylissabet, M. Taufiq, Kontribusi Babtsul Masail Pesantren di Madura dalam Menghadapi Perkembangan Hukum Islam Kontemporer, Jurnal Perada: Jurnal Studi Islam Kawasan Melayu, 2019.

Abu Bakar, I'anah al-Thalibin Ala Hilli AlFadz, Al-Mu'in, Darul Kutub.

Abu Hasan, Ali bin Ahmad Al-Wahidi, Asbab Al-nuzul Al-qur'an.

Al-Arabiyah, Musthafa Al-Babi Al-Halabi

Ali Bin Umar Al-Daruquthni, Sunan AlDaruquthni, Delhi India.
Dahlan Abdul Azis, Ensiklopedi Hukum Islam, PT Ichtiar Baru van Hoeve, Jakarta, 2001.

Faishal Haq, Drs dan Saiful Anam, Drs. H.A, Hukum wakaf dan Perwakafan di Indonesia, PT.Garoeda Buana Indah, 2004.

Fiqh Wakaf, Proyek peningkatan Pemberdayaan Wakaf Direktoral Jenderal Bimas Islam dan PenyelenggaraanHaji, 2004.

Himpunan Peraturan Perundangundangan Perwakafan Tanah Milik, Proyek Peningkatan Sarana Keagamaan Islam, Zakat dan Wakaf, Jakarta 1996/1997.

Huzaimah .Y Tangga, Pengantar Perbandingan Mazhab, Logos, J akarta, 1997.

Ibnu Qudamah, al-Mughni wa as-Syarth alKabir, edisi I, Beirut, Dar al-Fikr, 1984.

Imam Malik bin Anas Al-Asbahni, AlMuwatha", Syarh Al-Zarqani.

Imam Muhammad bin Idris Al-Syafi'i, $A l$ Umm, Al-Sya'bi.

Khuzaifah Dimyati, Dr, Teorisasi Hukum, Studi Perkembangan Pemikiran Hukum di Indonesia 1945-1990, universitan Muhammadiyah Jakarta, 2004.

Kompilasi Hukum Islam di Indonesia, Direktorat Pembinaan Badan Peradilan Agama Islam Direktorat jenderal Pembinaan Kelembagaan Agama Islam Departemen Agama RI, 2001.

Muhammad bin Ismail Al-Shan'ani, Subul Al-Salam, Musthafa Al-Babi AlHalabi.

Noeng Muhajir, Penelitian Kuantitatif, Yokyakarta, Rake sarasin, 1990.

Paradigma Baru Wakaf di Indonesia, direktorat Pengembangan zakat dan wakaf Direktorat jenderal Bimbingan Masyarakat Islam dan Penyelenggaraan Haji, 2005

Perkembangan Pengelolaan wakaf di Indonesia, Proyek Peningkatan 
Pemberdayaan Wakaf Direktorat Jenderal BimbinganMsyarakat Islam dan Penyelenggaraan haji, 2004.

Sayyid Sabiq, Figh Sunnah, Jilid III, Quwait, Dar al-Bayan, 1986.

Syam ad-Din as-sarakhsi, al-Mabsuth, Jus 5 , Beirut, Dar al-Ma'rifah, 1989.

Taufiq, M, Optimalisasi Peran Dewan Pengawas Syariah di Lembaga Keuangan Mikro Syariah, Al Huquq : Journal of Indonesian Islamic Economic Law, 2020.

Taufiq, M., dan Muklisin Purnomo, Model Pemberdayaan Aset Wakaf Masjid Secara Produktif Di Masjid Jogokariyan Yogyakarta, (Bintan : STAIN SAR KEPRI), PERADA : Jurnal Studi Islam Kawasan Melayu, Vol. 1, No. 2, 2018.

Taufiq Hamami. Drs. H, SH, Perwakafan Tanah dalam Politik Hukum Agraria, PT. Tatanusa, Jakarta Indonesia, 2003.

Undang-Undang Republik Indonesia Naomor 41 tahun 2004 Tentang Wakaf, Departemen Agama RI Direktorat Jenderal Bimas Islam dan Penyelenggaraan Haji, 2004 